\title{
Auer Rod Measurement
}

National Cancer Institute

\section{Source}

National Cancer Institute. Auer Rod Measurement. NCI Thesaurus. Code C74657.

The determination of the number of Auer rods present in a sample. 